\title{
Growth and nutrition of container-grown ponderosa pine seedlings with controlled-release fertilizer incorporated in the root plug
}

\author{
Zhaofei FAN ${ }^{\mathrm{a} *}$, James A. MOORE ${ }^{\mathrm{b}}$, David L. WENNY ${ }^{\mathrm{b}}$ \\ a Department of Forestry, The School of Natural Resources, 203 ABNR Building, University of Missouri-Columbia, Columbia, MO 65211, USA \\ $\mathrm{b}$ Department of Forest Resources, University of Idaho, Moscow, ID 83844-1133, USA
}

(Received 28 February 2002; accepted 22 April 2003)

\begin{abstract}
Prior to sowing seeds, three controlled-release fertilizers (fast release (FR), moderate release (MR) and slow release (SR)) were incorporated into the growing media at rates of $0.8,1.6$ or $3.2 \mathrm{~g}$ as supplements to nursery supplied soluble fertilizer to grow containerized ponderosa pine (Pinus ponderosa Doug. ex Laws) seedlings in the greenhouse. At lifting, the stem diameter, height and total mass of fertilized seedlings ranged from 14 to $29 \%, 15$ to $22 \%$, and 39 to $100 \%$ larger than those of the unfertilized seedlings, respectively. FR provided more balanced nutrients than did MR or SR. The root growth potentials of ponderosa pine treated with $3.2 \mathrm{~g}$ of MR or SR were much lower than those of other treatments, indicating that a $3.2 \mathrm{~g}$ rate of MR or SR was too high for the seedlings. The estimated best dosages for maximum caliper and height growth were $0.8,2.2$ and $2.0 \mathrm{~g}$ for FR, MR and SR fertilizers, respectively.
\end{abstract}

Pinus ponderosa Doug. Ex Laws / controlled-release fertilizer / biomass / root growth potential / foliar nutrient concentration

Résumé - Croissance et nutrition de plants de pin ponderosa élevés en container avec apport d'engrais à libération contrôlée incorporée dans le godet. On a incorporé, avant semis, dans le milieu de culture, des engrais à libération contrôlée [libération rapide (FR), libération modérée (MR) et libération lente (SR)] à des doses de 0,8,1,6 et 3,2 g, en supplément de l'apport d'engrais soluble utilisé pour l'élevage en container sous serre de plants de pin ponderosa (Pinus ponderosa Doug. ex Laws). En fin d'élevage, le diamètre des tiges, la hauteur et le poids total des plants fertilisés étaient supérieurs à ceux des plants non fertilisés, respectivement de 14 à $29 \%, 15$ à $22 \%$ et 39 à $100 \%$. FR assure un meilleur équilibre d'éléments nutritifs que MR et SR. Les potentiels de croissance racinaire ayant reçu 3,2 g de MR ou SR étaient inférieurs à ceux correspondant aux autres traitements, ce qui indique que la dose de 3,2 $\mathrm{g}$ de MR ou SR est trop élevée pour les plants. Pour obtenir le maximum de croissance en diamètre et hauteur, on estime que les meilleurs dosages sont respectivement de 0,8, 2,2 et 2,0 g pour FR, MR et SR.

Pinus ponderosa Doug. ex Laws / engrais à libération contrôlée / biomasse / potentiel de croissance des racines / concentration en éléments fertilisation des feuilles

\section{INTRODUCTION}

Tree seedling fertilization has been a topic of long-standing research interest in northwestern North America. Fertilization trials have been established to test not only fertilizer sources, application rate, application time and placement method but how these factors interact with stock type and cultural treatments such as site preparation and vegetation control to affect response magnitude and duration $[1,5,19]$. Steady-state nutrition theory [10-13] suggests that seedling growth and nutrient uptake can be maximized and leaching losses minimized by supplying small quantities of nutrients in proportion to requirements. Matching seedling growth with nutrient uptake using exponentially increasing application rates is important for maintaining steady-state nutrition and stable internal nutrient concentration in the plants. Short-term experiments with potted seedlings using nutrient-solution cultures showed that exponentially based fertilization achieved steady-state nutrition and enhanced plant nutrient status, uptake and growth.

Steady-state nutrition provides information on how to adjust nutrient loading patterns of conventional fertilization practices to achieve maximum nutrient uptake and growth performance, although its implementation with large scale field fertilization trials is impossible. However, fertilizer efficiency and growth performance can be improved to some degree if factors contributing to loss of fertilizer efficiency, such as the rapid dissolution and hydrolysis of the applied fertilizers, were controlled. Controlled-release fertilizers could be a solution to the low fertilization efficiency and non-significant response observed under certain circumstances. Several studies have reported slow-release

\footnotetext{
*Corresponding author: fanzha@missouri.edu
} 
fertilizers effects on tree growth and/or soil chemical properties [3, 8, 19-21]. [1] summarized research results from Canada dealing with controlled-release fertilizers incorporated in container grown seedling root plugs and pointed out that release rate and application rate were the key factors determining controlled-release fertilizer performance.

Application of controlled-release fertilizers is a promising management practice to ensure rapid establishment of new plantations in the Inland Northwest. On certain sites, controlled-release fertilizer could overcome problems usually associated with soluble fertilizers such as increased mortality caused by the osmotic effect of high salt concentration in the rooting zone, intensive competition from vegetation, and contamination of underground water system and rivers if the products were formulated and designed appropriately (nutrient composition and release characteristics), and were applied in a proper amount, placement method and timing. Moreover, controlledrelease fertilizers may also help decrease the labor cost of repeated fertilization practices of soluble fertilizers. However, little information is available currently for conditions and species commonly grown in the Inland Northwest of the United States.

In 1996, the Scotts Company and the Intermountain Forest Tree Nutrition Cooperative (IFTNC) at the University of Idaho cooperatively established an experiment to investigate the applicability of a number of different controlled-release fertilizer products. The fertilizers were either applied into the root plug of containerized ponderosa pine stock in the green house or applied into a hole $15 \mathrm{~cm}$ deep and $8 \mathrm{~cm}$ away from the planting point on the uphill side immediately after planting. Significant growth results were achieved with certain products using both placement methods on the field test $[7,14]$. In this paper, we present results from incorporating controlled-release fertilizers in the root plug of containerized stock, along with the regular nursery fertilization regime, on the growth and nutrition of containerized ponderosa pine stock during the 9-month growing period. Our hypothesis was that, in the greenhouse, incorporating extra controlled-release fertilizer might improve seedling morphological and chemical attributes, which in turn would improve field performance and establishment of new ponderosa pine plantations. Specifically, our study investigated the effect of three types of controlled-release products applied at three application rates on the growth, nutritional status, and root growth potential of ponderosa pine seedlings. Based on these results, we estimate the optimum controlled-release fertilizer application rates for growing containerized ponderosa pine seedlings in the greenhouse. Results from this experiment could provide an economically efficient fertilization regime, including appropriate products and application rates, to ensure rapid growth and establishment after outplanting.

\section{MATERIALS AND METHODS}

\subsection{Plant materials, controlled-release fertilizers, and growing environment}

Three types of controlled-release fertilizers (Tab. I) were tested at application rates of $0.8,1.6$ and $3.2 \mathrm{~g}$ per seedling. The containers used for growing ponderosa pine seedlings were the160/90 styroblock
Table I. Percent by weight of macronutrients and micronutrients provided by three controlled release fertilizers used in the ponderosa pine experiment.

\begin{tabular}{lrrr}
\hline Nutrient & \multicolumn{3}{c}{ Product } \\
\cline { 2 - 4 } & $\begin{array}{r}\text { Fast release } \\
(9 \text { months })\end{array}$ & $\begin{array}{r}\text { Moderate release } \\
(12-14 \text { months })\end{array}$ & $\begin{array}{c}\text { Slow release } \\
(16-20 \text { months })\end{array}$ \\
\hline $\mathrm{N}$ & 16 & 18 & 18 \\
$\mathrm{P}\left(\mathrm{P}_{2} \mathrm{O}_{5}\right)$ & 9 & 6 & 5 \\
$\mathrm{~K}\left(\mathrm{~K}_{2} \mathrm{O}\right)$ & 12 & 12 & 12 \\
$\mathrm{Ca}$ & 1.5 & 1.5 & 1.5 \\
$\mathrm{Mg}$ & 1 & 1 & 1 \\
$\mathrm{~B}$ & 0.02 & 0.02 & 0.02 \\
$\mathrm{Cu}$ & 0.05 & 0.05 & 0.05 \\
$\mathrm{Zn}$ & 0.05 & 0.05 & 0.05 \\
$\mathrm{Fe}$ & 0.4 & 0.4 & 0.4 \\
$\mathrm{Mn}$ & 0.1 & 0.1 & 0.1 \\
$\mathrm{Mo}$ & 0.001 & 0.001 & 0.001 \\
\hline
\end{tabular}

(160 90- $\mathrm{cm}^{3}$ cells per tray). A completely randomized design including 10 treatments ( 3 formulations $\times 3$ application rates and 1 control), each with 4 replicates (trays) was used in the experiment. For the three application rates, 128, 256, and $512 \mathrm{~g}$ of each of three controlledrelease fertilizers were first fully mixed with a $0.014 \mathrm{~m}^{3}$ of the $50 / 50$ percent peat-vermiculite growing media. Container cells were then hand filled with the mixture of growing media and fertilizers on February 24th, 1996. For the control treatment, no controlled-release products were incorporated in the growing media. Ponderosa pine seeds, collected from natural stands in northern Idaho within the same seed transfer zone as the planting site, were sown at 3 seeds/cell with a vacuum seeder and covered with about $0.6 \mathrm{~cm}$ of Target Forestry Sand ${ }^{\circledR}$ on March 1st. Once sowing was complete, the containers were irrigated until the media was thoroughly moist. Phosphoric acid was injected into the irrigation water to adjust $\mathrm{pH}$ to around 6.0. The seed germination process was completed by March 22nd and cells were then thinned to one seedling per cell when most seedlings shed their seed coats. During the growth phase (from March to June), day temperatures of $24-27^{\circ} \mathrm{C}$ and night temperatures around $18{ }^{\circ} \mathrm{C}$ were maintained. Photoperiod was extended to $24 \mathrm{~h}$ in the greenhouse by using iridescent bulbs. In addition to the fertilization treatments, the regular nursery-based liquid fertilizer solution was also applied during twiceweekly irrigations through an overhead traveling boom system. Top dressing rates and nutrient compositions for the regular nursery fertilization regime were adjusted based on seedling growth phases. The growing regime for ponderosa pine is described in detail in [22].

\subsection{Measurement of root-collar diameter, height, biomass, root growth potential, and foliar nutrient concentrations of ponderosa pine seedlings}

Root-collar diameter and height (from the root collar to the base of the dominant bud) were measured at the end of each month starting from March to September through a systematic sample of 32 seedlings for each treatment ( 8 seedlings per replicate). At lifting (December 1, 1996), these seedlings were then cut at the root collar, and the root system was extracted from the container and hand washed. The shoot was separated into needles and stem. The needle, stem and root samples were weighed after oven drying at $70^{\circ} \mathrm{C}$ for $48 \mathrm{~h}$. The shoot/root ratio was calculated as the shoot (needle + stem) mass to the root mass. Needle 
samples were then ground and sent to the Scotts Company Laboratories in Allentown, PA for analysis of N, P, K, Ca, Mg, B, Cu, Zn, Fe, $\mathrm{Mn}$ and Mo concentrations. Foliar nitrogen was determined using a standard mico-Kjeldahl procedure. Phosphorus, K, Ca, Mg, Mn, Mo, $\mathrm{Fe}, \mathrm{Cu}$ and $\mathrm{Zn}$ were determined by inductively coupled plasma (ICP) emission with digested plant tissue.

The remaining seedlings from each treatment were wrapped with plastic in bundles of 20 after lifting and placed into polylined wax boxes for cold storage. The refrigerated storage is kept at $0.5^{\circ} \mathrm{C}$ with relative humidity near 100 percent. Seedlings were then outplanted in late April of the next year (1997). [14] described in detail the field experimental design and seedling growth during the first 2 years .

Before outplanting, thirty-two seedlings for each treatment were randomly selected for root growth potential testing. A completely randomized design with four replicates was employed. Seedlings were placed in 3.78-liter pots filled with the 50/50 percent peat-vermiculite growing media and grown in the same greenhouse environment as before. Seedlings were watered to maintain the maximum water-holding potential for the media. The root growth potential experiment ended four weeks later after $80 \%$ of the buds had broken dormancy. Roots were extracted from the pots and the medium was washed carefully from them. Root growth potential index was evaluated based on the following criteria [2]: 0: no new roots growth; 1 : some new roots but none over $1 \mathrm{~cm}$ long; $2: 1-3$ new roots over $1 \mathrm{~cm}$ long; $3: 4-10$ new roots over $1 \mathrm{~cm}$ long; 4: $11-30$ new roots over $1 \mathrm{~cm}$ long; 5 : > 30 new roots over $1 \mathrm{~cm}$ long.

\section{DATA ANALYSIS}

\subsection{Seedling growth}

We employed the Chapman-Richards growth function [4, 9, $16,17]$ of the form:

$$
y=A\{1-\exp (-k t)\}^{\frac{1}{1-m}}
$$

to study the growth of ponderosa pine seedling's stem diameter (D), height $(\mathrm{H})$ and volume (V, approximately calculated as $\left.\pi \mathrm{D}^{2} \mathrm{H} / 4\right)$ under different fertilization treatments. Where $y$ represents the stem diameter $(\mathrm{mm})$, height $(\mathrm{cm})$ or volume $\left(\mathrm{cm}^{3}\right)$, $t$ is the time (month) since seeding (March 1, 1996), and $A, k$, and $m$ are the parameters to be estimated. To block out the potential effect from seed quality and the cell-to-cell variation in the amount of controlled-release fertilizers due to the cell filling method, stem diameter, height and volume means for each replicate $(y)$ were used rather than stem diameter, height and volume of individual seedlings. Therefore, we have 4 data points for each response variable corresponding to each of the 7 measuring dates, respectively. We set the initial (March 1, 1996, seeding) stem diameter, height and volume as zero and included this point in our model fitting process. We also calculated the maximum growth rate $(Y \max )$ and the time (Tmax) at the inflection point for each growth curve using equations (2) and (3) based on the estimated $A, k$, and $m$.

$$
\begin{gathered}
Y \max =A k m^{\frac{m}{1-m}} \\
T \max =[-\ln (1-m)] / k .
\end{gathered}
$$

We used the NLIN procedure [15] to fit model (1). We estimated the initial value of parameters $A, k$ and $m$ as 3.9, 0.5 and 0.3, and 17, 0.9 and 0.7 , and 3.0, 0.7 and 0.5 for $\mathrm{D}, \mathrm{H}$ and $\mathrm{V}$, respectively, and used the Gauss-Newton iterative method to achieve the best least square fit.

\subsection{Mass production, allocation, foliar nutrient status, and root growth potential}

A generalized linear model (GLM) shown by (4) was employed to analyze the fertilization effect on final seedling stem diameter, height, total mass, shoot/root ratio and foliar nutrient concentrations.

$$
Y_{i j}=\mu+\operatorname{trea}_{i}+\varepsilon_{i j}(\mathrm{i}=1, \ldots, 10 ; \mathrm{j}=1, \ldots, 4)
$$

where $Y_{i j}$ is the average seedling stem diameter, height, total mass, shoot/root ratio, or foliar nutrient concentrations for replicate $j$ of treatment $i, \mu$ is the grand mean, trea ${ }_{i}$ is the fixed effect for treatment $i$, and $\varepsilon_{i j}$ is the error effect and is assumed to follow $\mathrm{N}\left(0, \sigma^{2}\right)$. Pairwise comparison of treatment means were performed using the Ryan-Gabriel-Welsch (RGWQ) multiplerange test at the experimental error rate $p=0.05$. Correlation between the seedling size at lifting in the greenhouse and at the end of the 2-year field test was generally evaluated using Pearson's correlation coefficient. Root growth potential data were analyzed using the PROC FREQ of SAS [15].

\subsection{Estimating application rates for growing containerized ponderosa pine seedlings with maximum stem diameter and height}

Regression of the final seedling stem diameter and height on fertilizer application rates was conducted for each controlled-release product using a parabolic model of the form:

$$
Y_{i}=a_{0}+a_{1} X+a_{2} X^{2}+\varepsilon_{i}(i=1,2,3,4)
$$

where $Y_{i}$ is the average root-collar diameter $(\mathrm{mm})$ or height $(\mathrm{cm})$ for replicate $i, X$ is the application rate, $a_{0}, a_{1}$ and $a_{2}$ are the regression parameters, and $\varepsilon_{i}$ is the random error. The estimated application rate associated with maximum caliper and height for each fertilizer type was calculated via differentiation as follows:

$$
\text { estimated application rate }=-\hat{a}_{1} /\left(2 \hat{a}_{2}\right) .
$$

For simplicity in the presentation of results, we use CTR to represent the control (no controlled release fertilizer added), and FR-0.8, FR-1.6, and FR-3.2 to represent the 0.8, 1.6 and $3.2 \mathrm{~g}$ per seedling of the FR fertilizer treatments. The moderate release $(\mathrm{MR})$ and slow release $(\mathrm{SR})$ treatments are similarly designated.

\section{RESULTS}

Stem diameter, height and volume growth of ponderosa pine seedlings under all fertilizer treatments in the green house was well described by the Chapman-Richards function (Fig. 1 and Tab. II); no evidence of detectable residual patterns and lackof-fit were found with the fitted models $(p<0.001)$. Controlledrelease fertilizer treatment effects on seedling stem diameter 

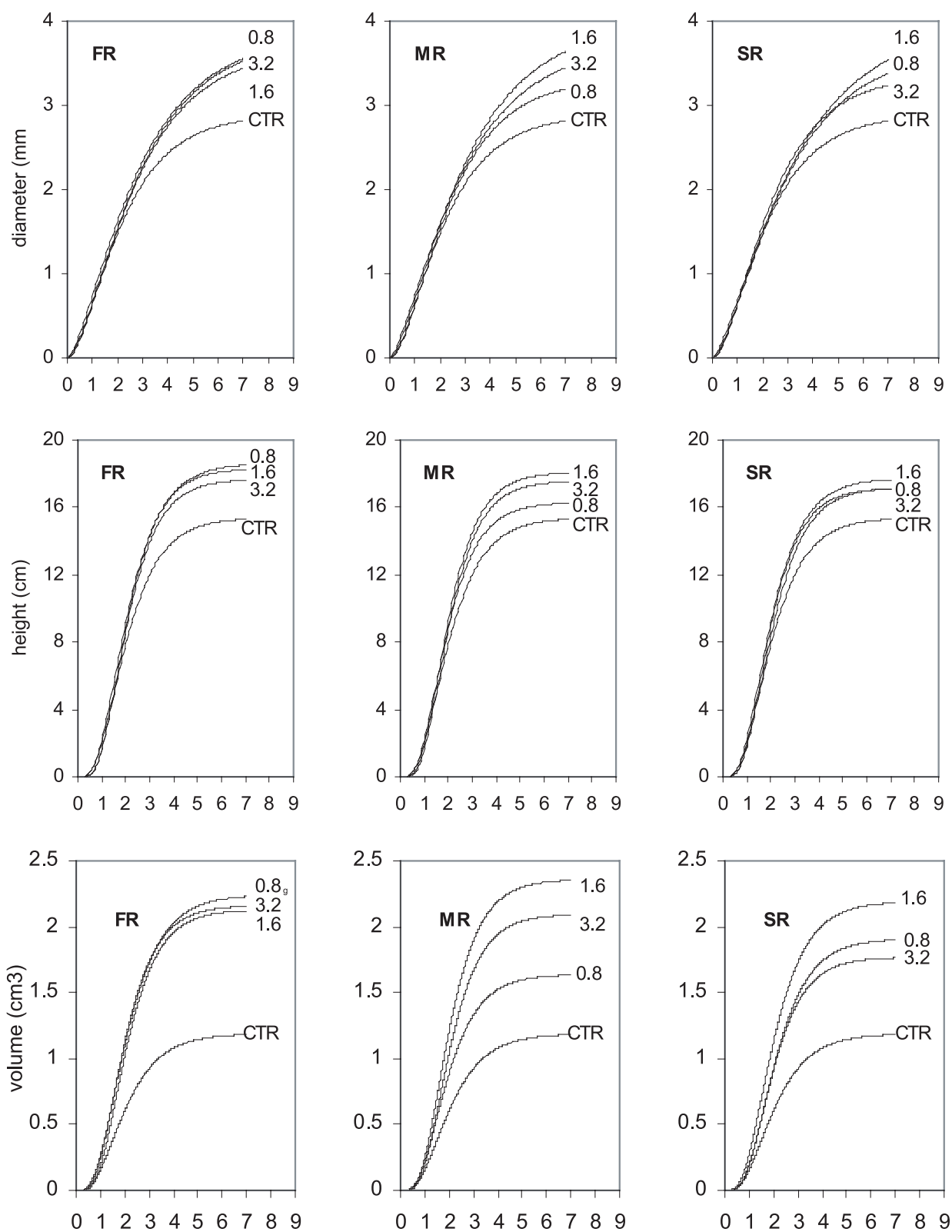

month after sowing

Figure 1. The fitted Chapman-Richards growth curves of stem diameter (D), height $(\mathrm{H})$ and volume $(\mathrm{V})$ of ponderosa pine seedlings under different fertilization treatments (the sowing date is March 1st, 1996).

and height growth were not evident until May (third month after sowing), yet the controlled-release fertilizer treatment effect on stem volume was detected by early April, one month after sowing. Stem height and volume growth of seedlings treated with controlled-release fertilizers accelerated until the end of June (bud initiation, fourth month after sowing); subsequently, stem height and volume approached the plateau and gained little from controlled-release fertilizer treatment. Stem diameter growth, however, continually accelerated until late September (seventh month after sowing, Fig. 1). The inflection point of the stem diameter, height, and volume growth curves was located in early or middle April $(1<T \max <2)$, and there was no difference among treatments (Tab. II). The maximum growth rate of stem height and volume of seedlings treated with controlledrelease fertilizer was larger than the control, but the maximum treated seedling stem diameter growth rate was not different from the control.

At lifting, controlled-release fertilizer treatments as a group produced larger stem diameter $(3.2 \sim 3.6 \mathrm{~mm})$, height $(16.6 \sim$ $18.0 \mathrm{~cm})$ and total mass $(3.2 \sim 4.6 \mathrm{~g})$ than the control treatment 
Table II. Parameter estimates of the Chapman-Richards growth model (1) for stem diameter (D), height (H) and volume (V) of ponderosa pine seedlings under different fertilization treatments.

\begin{tabular}{|c|c|c|c|c|c|c|c|c|c|c|c|}
\hline & & CTR & FR-0.8 & FR-1.6 & FR-3.2 & MR-0.8 & MR-1.6 & MR-3.2 & SR-0.8 & SR-1.6 & SR-3.2 \\
\hline \multirow{5}{*}{$\mathrm{D}$} & A & 2.89 & 3.83 & 3.67 & 3.80 & 3.32 & 3.97 & 3.74 & 3.66 & 3.98 & 3.35 \\
\hline & $\mathrm{k}$ & 0.62 & 0.42 & 0.48 & 0.45 & 0.57 & 0.42 & 0.42 & 0.44 & 0.37 & 0.58 \\
\hline & $\mathrm{m}$ & 0.48 & 0.38 & 0.45 & 0.42 & 0.50 & 0.39 & 0.34 & 0.41 & 0.33 & 0.50 \\
\hline & $Y \max$ & 0.91 & 0.89 & 0.92 & 0.91 & 0.95 & 0.91 & 0.90 & 0.87 & 0.85 & 0.97 \\
\hline & $T \max$ & 1.05 & 1.14 & 1.25 & 1.21 & 1.22 & 1.18 & 0.99 & 1.20 & 1.08 & 1.20 \\
\hline \multirow{5}{*}{$\mathrm{H}$} & A & 15.39 & 18.63 & 18.30 & 17.67 & 16.30 & 18.10 & 17.57 & 17.19 & 17.72 & 17.15 \\
\hline & $\mathrm{k}$ & 0.94 & 0.95 & 1.05 & 1.06 & 1.04 & 1.07 & 1.09 & 0.99 & 0.99 & 1.07 \\
\hline & $\mathrm{m}$ & 0.75 & 0.77 & 0.82 & 0.80 & 0.78 & 0.81 & 0.83 & 0.79 & 0.77 & 0.81 \\
\hline & $Y \max$ & 6.10 & 7.38 & 7.78 & 7.67 & 7.03 & 7.89 & 7.71 & 7.01 & 7.31 & 7.47 \\
\hline & $T \max$ & 1.47 & 1.55 & 1.63 & 1.51 & 1.46 & 1.55 & 1.63 & 1.58 & 1.48 & 1.55 \\
\hline \multirow{5}{*}{ V } & A & 1.19 & 2.24 & 2.12 & 2.16 & 1.64 & 2.36 & 2.10 & 1.91 & 2.19 & 1.77 \\
\hline & $\mathrm{k}$ & 0.94 & 0.95 & 1.05 & 1.06 & 1.04 & 1.08 & 1.09 & 0.99 & 0.98 & 1.08 \\
\hline & $\mathrm{m}$ & 0.75 & 0.77 & 0.82 & 0.80 & 0.78 & 0.81 & 0.83 & 0.80 & 0.77 & 0.81 \\
\hline & $Y \max$ & 0.47 & 0.89 & 0.90 & 0.94 & 0.71 & 1.04 & 0.92 & 0.77 & 0.89 & 0.79 \\
\hline & $T \max$ & 1.47 & 1.55 & 1.63 & 1.52 & 1.46 & 1.54 & 1.63 & 1.63 & 1.50 & 1.54 \\
\hline
\end{tabular}

(2.8 mm, $14.8 \mathrm{~cm}$ and $2.3 \mathrm{~g}$, respectively) ( $p<0.01)$. Fertilized seedlings were $14-29,15-22$, and 39-100\% larger than the controls. Pairwise comparisons of treatment means further showed that all treatments with FR product produced significantly larger stem diameter, height and total mass than the control treatment. However, for the MR and SR products, only the moderate level (1.6 g per seedling) always produced significantly larger stem diameter, height and total mass compared to the control treatment. Certain low and/or high levels $(0.8$ and $3.2 \mathrm{~g}$ per seedling, respectively) of MR or SR product were not significantly different from the controls in stem diameter, height or total mass (Tab. III).

The shoot/root ratio of ponderosa pine seedlings treated with controlled-release fertilizer increased as application rate increased. The ratios ranged from $2.8 \sim 3.7$ compared to 2.2 for the control treatment (Tab. III). One-way analysis of variance indicated that controlled-release fertilizer treatments as a group significantly increased shoot/root ratio $(p=0.015)$. But, the comparison of treatment means found that only the FR-3.2 treatment was statistically different from the control.

Overall, foliar concentrations of $\mathrm{N}(p=0.0010), \mathrm{Mg}(p=$ $0.0210), \mathrm{B}(p<0.0001), \mathrm{Cu}(p<0.0001), \mathrm{Fe}(p=0.0011)$ and Mo $(p=0.0155)$ were significantly affected by controlledrelease fertilizer treatments. Comparison of foliar nutrient concentration means showed that certain treatments (i.e., MR-3.2, SR-3.2 and SR-0.8) were significantly different from the control for foliar B, Cu and $\mathrm{Fe}$ concentrations. Foliar N, Mg and Mo concentrations differed only among controlled-release fertilizer treatments. No significant differences $(p=0.05)$ among treatments were found for other nutrients (Tab. IV).
Table III. Pairwise comparisons of means of stem diameter (D), height (H), total mass (TM) and shoot/root ratio at lifting, and root growth potential (RGP) at outplanting of ponderosa pine seedlings (means labeled with the same letters are statistically nonsignificant at the REGWQ multiple-range test $p=0.05$ ).

\begin{tabular}{lccccc}
\hline Treatment & D (mm) & H $(\mathrm{cm})$ & TM $(\mathrm{g})$ & Shoot/root & RGP \\
\hline Control & $2.8 \mathrm{~b}$ & $14.8 \mathrm{~b}$ & $2.3 \mathrm{~b}$ & $2.2 \mathrm{~b}$ & $3.7 \mathrm{ab}$ \\
FR-0.8 & $3.5 \mathrm{a}$ & $18.0 \mathrm{a}$ & $4.3 \mathrm{a}$ & $2.9 \mathrm{ab}$ & $4.5 \mathrm{a}$ \\
FR-1.6 & $3.4 \mathrm{a}$ & $17.7 \mathrm{a}$ & $4.1 \mathrm{a}$ & $3.1 \mathrm{ab}$ & $4.1 \mathrm{ab}$ \\
FR-3.2 & $3.5 \mathrm{a}$ & $17.1 \mathrm{a}$ & $4.2 \mathrm{a}$ & $3.7 \mathrm{a}$ & $3.5 \mathrm{ab}$ \\
MR-0.8 & $3.2 \mathrm{ab}$ & $15.8 \mathrm{ab}$ & $3.2 \mathrm{ab}$ & $2.6 \mathrm{ab}$ & $3.8 \mathrm{ab}$ \\
MR-1.6 & $3.6 \mathrm{a}$ & $17.5 \mathrm{a}$ & $4.6 \mathrm{a}$ & $2.9 \mathrm{ab}$ & $3.9 \mathrm{ab}$ \\
MR-3.2 & $3.4 \mathrm{a}$ & $16.9 \mathrm{ab}$ & $4.0 \mathrm{a}$ & $3.0 \mathrm{ab}$ & $2.8 \mathrm{c}$ \\
SR-0.8 & $3.3 \mathrm{a}$ & $16.6 \mathrm{ab}$ & $3.6 \mathrm{ab}$ & $2.8 \mathrm{ab}$ & $4.2 \mathrm{ab}$ \\
SR-1.6 & $3.5 \mathrm{a}$ & $17.3 \mathrm{a}$ & $4.3 \mathrm{a}$ & $3.0 \mathrm{ab}$ & $3.9 \mathrm{ab}$ \\
SR-3.2 & $3.2 \mathrm{ab}$ & $16.6 \mathrm{ab}$ & $3.4 \mathrm{ab}$ & $3.0 \mathrm{ab}$ & $2.3 \mathrm{~d}$ \\
\hline
\end{tabular}

After 5 months of cold storage, root growth potential of ponderosa pine seedlings treated with $3.2 \mathrm{~g}$ of MR or SR product was significantly lower than the control as well as all other controlled-release fertilizer treatments (Tab. III). A large number of dead root plugs were found with the $3.2 \mathrm{~g}$ of MR or SR treatments. Treatment FR- 0.8 produced more seedlings with root growth potential indexes in categories 4 and 5 than other treatments; however, the differences were not statistically significant at $p=0.05$. A supplemental fertilizer release test conducted 
Table IV. Average foliar nutrient concentrations of ponderosa pine seedlings at lifting (December) for various fertilization treatments (means labeled with the same letters are statistically nonsignificant at the REGWQ multiple-range test $p=0.05$ ).

\begin{tabular}{|c|c|c|c|c|c|c|c|c|c|c|}
\hline CTR & FR-0.8 & FR-1.6 & FR-3.2 & MR-0.8 & MR-1.6 & MR-3.2 & SR-0.8 & SR-1.6 & SR-3.2 & \\
\hline $\mathrm{N}(\%)$ & $2.25 \mathrm{ab}$ & $2.31 \mathrm{ab}$ & $2.24 \mathrm{ab}$ & $2.37 \mathrm{ab}$ & $2.64 \mathrm{a}$ & $2.42 \mathrm{ab}$ & $2.73 \mathrm{a}$ & $2.47 \mathrm{ab}$ & $2.00 \mathrm{~b}$ & $2.06 \mathrm{~b}$ \\
\hline $\mathrm{P}(\%)$ & $0.27 \mathrm{a}$ & $0.27 \mathrm{a}$ & $0.28 \mathrm{a}$ & $0.29 \mathrm{a}$ & $0.28 \mathrm{a}$ & $0.29 \mathrm{a}$ & $0.32 \mathrm{a}$ & $0.29 \mathrm{a}$ & $0.28 \mathrm{a}$ & $0.29 \mathrm{a}$ \\
\hline $\mathrm{K}(\%)$ & $1.07 \mathrm{a}$ & $1.05 \mathrm{a}$ & $1.07 \mathrm{a}$ & $1.05 \mathrm{a}$ & $1.14 \mathrm{a}$ & $1.10 \mathrm{a}$ & $1.19 \mathrm{a}$ & 0.99 a & $1.00 \mathrm{a}$ & $1.00 \mathrm{a}$ \\
\hline $\mathrm{Ca}(\%)$ & $0.17 \mathrm{a}$ & $0.16 \mathrm{a}$ & $0.18 \mathrm{a}$ & $0.17 \mathrm{a}$ & $0.20 \mathrm{a}$ & $0.18 \mathrm{a}$ & $0.18 \mathrm{a}$ & $0.18 \mathrm{a}$ & $0.21 \mathrm{a}$ & $0.20 \mathrm{a}$ \\
\hline $\operatorname{Mg}(\%)$ & $0.14 \mathrm{ab}$ & $0.13 \mathrm{~b}$ & $0.16 \mathrm{ab}$ & $0.14 \mathrm{ab}$ & $0.15 \mathrm{ab}$ & $0.15 a b$ & $0.15 \mathrm{ab}$ & $0.17 \mathrm{ab}$ & $0.17 \mathrm{ab}$ & $0.18 \mathrm{a}$ \\
\hline $\mathrm{B}(\mathrm{ppm})$ & $32 \mathrm{~d}$ & $37 \mathrm{~d}$ & $35 \mathrm{~d}$ & $41 \mathrm{~cd}$ & $38 \mathrm{~d}$ & $37 \mathrm{~d}$ & $50 \mathrm{~b}$ & $62 \mathrm{a}$ & $37 \mathrm{~d}$ & $49 \mathrm{bc}$ \\
\hline $\mathrm{Cu}(\mathrm{ppm})$ & $9.0 \mathrm{bc}$ & $8.8 \mathrm{bc}$ & $9.9 \mathrm{~b}$ & $9.3 \mathrm{~b}$ & $11.7 \mathrm{ab}$ & $11.0 \mathrm{ab}$ & $13.5 \mathrm{a}$ & $5.9 \mathrm{~cd}$ & $8.8 \mathrm{bc}$ & $4.9 \mathrm{~d}$ \\
\hline $\mathrm{Zn}(\mathrm{ppm})$ & $48 \mathrm{a}$ & $45 \mathrm{a}$ & $50 \mathrm{a}$ & $76 \mathrm{a}$ & $88 \mathrm{a}$ & $67 \mathrm{a}$ & $104 \mathrm{a}$ & $90 \mathrm{a}$ & $70 \mathrm{a}$ & $90 \mathrm{a}$ \\
\hline $\mathrm{Fe}(\mathrm{ppm})$ & $211 b c$ & $209 \mathrm{bc}$ & $215 \mathrm{bc}$ & $214 \mathrm{bc}$ & $195 \mathrm{c}$ & $210 \mathrm{bc}$ & $235 a b c$ & $223 a b c$ & $257 \mathrm{ab}$ & $271 \mathrm{a}$ \\
\hline Mn (ppm) & $147 \mathrm{a}$ & $135 \mathrm{a}$ & $149 \mathrm{a}$ & $135 \mathrm{a}$ & $194 \mathrm{a}$ & $207 \mathrm{a}$ & $193 \mathrm{a}$ & $246 \mathrm{a}$ & $197 \mathrm{a}$ & $183 \mathrm{a}$ \\
\hline Mo (ppm) & $0.55 \mathrm{ab}$ & $0.32 \mathrm{~b}$ & $0.55 \mathrm{ab}$ & $0.45 \mathrm{ab}$ & $0.41 \mathrm{ab}$ & $0.40 \mathrm{ab}$ & $0.45 \mathrm{ab}$ & $0.49 \mathrm{ab}$ & $0.51 \mathrm{ab}$ & $0.61 \mathrm{a}$ \\
\hline
\end{tabular}

by measuring weight loss before and after cold storage showed that nutrients were continuously released from the fertilizer pellets during cool storage. The amount of nutrients released from $3.2 \mathrm{~g}$ of MR and SR fertilizer was $0.295(9.21 \%)$ and 0.142 $(4.43 \%) \mathrm{g}$, respectively.

As indicated by the growth curves (Fig. 1) or by the final seedling size (Tab. III), there was larger variation among the three application rates of MR or SR compared to FR. Caliper and height means for the $1.6 \mathrm{gm}$ rate were both largest among the three application rates for the MR and SR fertilizer types. The application rates which produced the maximum caliper and height growth were $2.2 \mathrm{~g}$ for the MR product and $2.0 \mathrm{~g}$ for the SR product, respectively, based on parabolic regression results of caliper and height on the application rates for the MR and SR fertilizer products and calculations from equation (6). Residual analysis showed no detectable pattern when fitting equation (5) to the data and the lack-of-fit was non-significant. Since all rates of the FR product produced about the same average caliper and height, we did not estimate a "maximum response" application rate. However, total mass favors the $0.8 \mathrm{~g}$ per tree rate. Correlation analysis showed the seedling size (diameter and height) two years after outplanting was strongly positively correlated with the final greenhouse seedling size (Tab. V).

\section{DISCUSSION}

Matching plant/seedling growth with nutrient uptake and maintaining stable internal nutrient concentration has been a topic of interest for many studies (e.g., [10-13]) to improve fertilization efficiency and to prevent nutrient deficiency, toxicity or environmental contamination due to rapid dissolution and hydrolysis. Controlled-release fertilizers could be a solution to rapid dissolution and hydrolysis by gradually providing seedlings with nutrients over a longer time period, although it was extraordinarily difficult or even impossible to achieve the ideal steady-state nutrition in real fertilization operations due to the technical difficulty in matching nutrient release rate and stock
Table V. Pearson's correlation coefficient between greenhouse and 2nd year field growth (numbers in parenthesis represent the significance level).

\begin{tabular}{ccccc}
\hline & \multicolumn{3}{c}{ Greenhouse } \\
\cline { 3 - 5 } & & Diameter & Height & Total mass \\
& \multirow{4}{*}{ Field } & 0.85 & 0.80 & 0.84 \\
& & $(0.002)$ & $(0.006)$ & $(0.002)$ \\
& \multirow{2}{*}{ Height } & 0.82 & 0.85 & 0.85 \\
& & $(0.004)$ & $(0.002)$ & $(0.002)$ \\
\hline
\end{tabular}

growth. However, the concept of steady-state nutrition pointed the direction for the design, formulation and application of controlled-release products. Thus, the practical significance of this study was testing the applicability of incorporating extra controlled-release fertilizer in the root plug under the regular nursery fertilization regime to grow high quality containerized ponderosa pine stock. This fertilization regime as a new nutrient uploading method may prevent the extreme nutrient deficiency or toxicity conditions, thus maintaining a reasonable stock nutritional status (range) to stimulate stock growth over a long period.

The three release products (FR, MR and SR) used in this study were formulated to incorporate both macro- and micronutrients inside the coating material as shown in Table I. The fertilizers were designed to release nutrients over a period of 9, 12 14, and 16 20 months, respectively. As shown by Figure 1 and Table II, ponderosa pine seedling growth was significantly improved by the incorporated controlled-release fertilizers. The magnitude varied by product (release period) and the application rate. The final stem diameter, height and total mass averaged over the three application rates of each controlled-release product showed that FR was superior to MR, and MR was superior to SR. This was most probably because the release period of FR matched the 9-month greenhouse seedling production period (from March to November); FR provided 
more nutrients than MR or SR for the rapid seedling growth early in the growing season (from April to June). However, the effect of product release period may have been compensated for in part by the application rate. For example, with the medium application rate the variation in diameter, height and total mass between FR, MR and SR was much smaller than that with the low and high application rates (Tab. II). This suggests that the medium application rate of these three products well matched the nutrient uptake process during the nine-month growing period. For the FR product, $0.8 \mathrm{~g}$ per seedling was best for height growth, while caliper and total mass growth did not increase with higher application rates of this fertilizer. This result was likely due to the additional nutrients leaching out of the container early in the growing season before they were needed and could be absorbed by the seedlings. For the MR or SR products, stem diameter, height and total mass growth patterns were similar, with the medium application rate exceeding the low and high application rates. The medium application rate of these two products produced significantly larger diameter, height and total mass than the control treatment, while certain low and high application rates did not. A probable interpretation of these results is that the low application rate of these two products provided inadequate nutrients during the early rapid seedling growth as indicated by Figure 1 and the high application rate was too high and poorly matched seedling growth requirements.

Large seedlings are usually desirable to overcome vegetation competition on the reforestation site, and can shorten the plantation establishment period. However, other planting stock quality characteristics such as shoot/root ratio or nutritional status were also important to the field performance of the planted stock and reforestation success, particularly on harsh sites [21]. Low shoot/root ratios favored field survival, root growth potential and improved growth potential on dry sites [18]. In the Inland Northwest, many reforestation sites experience a very dry period from mid-July until late September. Soil moistures at the seedling root zone $(10-40 \mathrm{~cm}$ depth) during this period were below $25 \%$ [7]. Outplanting is conducted either before or after the dry period and morphologically and physiologically suitable containerized stock should be used for reforestation in this region [6]. In our study, seedling growth was improved significantly by most controlled-release fertilizer treatments, but the shoot/root ratio, root growth potential and foliar nutritional status of seedlings treated with the low and moderate application rates of FR, MR or SR were not significantly different from those treated with the regular nursery fertilization regime (the control) (Tabs. III and IV). The regular nursery fertilization regime was designed to produce high-quality commercial containerized ponderosa pine stock for reforestation in north central Idaho [22]. Using the seedlings grown under the regular nursery fertilization regime as a reference, we quantitatively compared the effects of controlled-release products and application rates on major morphological and physiological traits. All these results indicate that both release rate and application rate should be carefully considered to achieve an optimum nutrient supply needed to grow larger seedlings with adequate nutrition.

Compared with a study on a neighboring site where controlledrelease products were applied adjacent to seedlings immediately after planting, incorporating the controlled-release prod- uct in the root plugs of containerized ponderosa pine stock in the nursery probably is a more efficient method in terms of field growth performance. Root plug fertilized seedlings were taller and had larger stem diameter during the first two years after outplanting $[7,14]$. We found that the difference in seedling stem diameter and height after two years between these two fertilization placement methods was mainly due to initial size differences of the planting stock (Tab. V) since the relative growth rate of seedlings treated by these two placement methods are comparable after outplanting [7, 14]. However, one potential problem with incorporating controlled-release fertilizers in container seedling root plugs is continuous nutrient release during cold storage. This release can cause high salinity buildup and toxicity, which in turn causes serious damage to seedling root systems [1]. Results of our root growth potential test confirmed this point. The MR-3.2 and SR-3.2 treatments caused much lower root growth potential than the same rate of FR fertilizer. This result was likely related to longer release periods for the MR and SR fertilizers. Our test of the MR and SR fertilizers release during cold storage supports the idea that continuous nutrient release and subsequent salinity buildup in the root plug are a possible reason for the lower root growth potential. This result suggests that for MR and SR fertilizers the $3.2 \mathrm{~g}$ per seedling rate is too high. Two years after planting, the seedling survival rate for these two treatments was only 45 and $63 \%$, which was significantly lower than any other treatment [14]. Therefore, when incorporating controlled-release fertilizer in the root plug, the release characteristics and application rate of controlled-release products must be well matched to the size of the containerized stock and nursery growing regime to achieve a better field survival rate. Given these small containers, lower application rates and shorter release periods should be used to prevent root damage when cold storage is required before outplanting. Longer fertilizer release periods may be appropriate if fall planting is used, thereby avoiding cold storage. Incorporating controlled-release fertilizers in the root plug of the containerized stock is a practical way to increase seedling size without dramatically changing desirable morphological and physiological traits such as shoot/root ratio, root growth potential and foliar nutrient status, if fertilizer nutrient release characteristics and application rates are correctly selected.

\section{CONCLUSIONS}

Controlled-release fertilizer placed in the container at the time of sowing increased diameter, needle, stem and total biomass of ponderosa pine seedlings at lifting in the greenhouse. Seedlings with controlled-release fertilizer incorporated in the root plug had larger stem diameter, height and total mass than seedlings with no controlled-release fertilizer incorporated. The estimated dosage to achieve maximum caliper and height in the greenhouse was 2.2 and $2.0 \mathrm{~g}$ per seedling for MR and SR fertilizer, respectively, while for FR fertilizer, the $0.8 \mathrm{~g}$ per seedling rate was best.

Seedlings treated with controlled-release fertilizer had larger shoot/root ratios compared to untreated seedlings, but the differences were not significant for all treatments except FR3.2. Seedlings treated with FR had a more balanced nutritional status than seedlings fertilized with MR or SR. Differences 
between MR and SR were not evident. Micro-nutrient deficiencies were more severe than macro-nutrients with either the MR or SR fertilizers. The MR-3.2 and SR-3.2 treatments resulted in much lower root growth potential probably due to toxicity caused by continuous nutrient release before or during cold storage. Many dead root plugs were found for these two treatments. The release period of the fast release fertilizer more closely matched the nursery's growing season length compared to longer release products. The FR product was therefore generally more effective in producing larger seedlings with wellbalanced biomass components.

Acknowledgments: The authors thank the Scotts Company and members of the Intermountain Forest Tree Nutrition Cooperative for supporting the project. Additional assistance from the University of Idaho Forest Research Nursery and the University of Idaho Experimental Forest is gratefully acknowledged. The authors also thank the associate editor and two anonymous reviewers for their constructive comments.

\section{REFERENCES}

[1] Brockley R.P., The effects of fertilization on the early growth of planted seedlings: a problem analysis, FRDA report 011, B.C. Ministry of Forests and Lands, Canada, 1988.

[2] Burdett A.N., New methods for measuring root growth capacity: their value in assessing lodgepole pine stock quality, Can. J. For. Res. 9 (1979) 63-67.

[3] Carlson W.C., Effects of controlled-release fertilizers on shoot and root development of outplanted western hemlock (Tsuga heterophylla Raf. Sarg.) seedlings, Can. J. For. Res. 11 (1981) 752-757.

[4] Causton D.R., Venus J.C., The biometry of plant growth, Edward Arnold, London, 1981.

[5] Donald D.G.M., Nursery fertilization of conifer planting stock, in: Van den Driessche R. (Ed.), Mineral nutrition of conifer seedlings, CRC Press, Boca Raton, FL, 1991, pp. 135-167.

[6] Fan Z., Response of ponderosa pine to controlled-release fertilizers, Ph.D. dissertation, University of Idaho, Moscow, ID, 1999.
[7] Fan Z., Moore J.A., Shafii B., Osborne H.L., Three-year response of ponderosa pine seedlings to controlled-release fertilizer applied at planting, West. J. Appl. For. 3 (2002) 154-164.

[8] Hunt G.A., Effect of controlled-release fertilizers on growth and mycorrhizae in container-grown Engelmann spruce, West. J. Appl. For. 4 (1989) 129-131.

[9] Hunt R., Plant growth curves-the functional approach to plant growth analysis, Edward Arnold, London, 1982.

[10] Ingestad T., Towards optimum fertilization, Ambio 3 (1974) 49-54.

[11] Ingestad T., Nitrogen and plant growth: maximum efficiency of nitrogen fertilizers, Ambio 6 (1977) 146-151.

[12] Ingestad T., Agren G.I., Nutrient uptake and allocation at steadystate nutrition, Physiol. Plant. 72 (1988) 450-459.

[13] Ingestad T., Lund A., Theory and techniques for steady state mineral nutrition and growth of plants, Scand. J. For. Res. 1 (1986) 439453.

[14] Moore J.A., Fan Z., Shafii B., Effect of root-plug incorporated controlled-release fertilizer on two-year growth and survival of planted ponderosa pine seedlings, West. J. Appl. For. 4 (2002) 216-219.

[15] SAS Institute, SAS user's guide, Vol. 2, SAS Institute, Inc. Cary, NC, 1995.

[16] Pienaar L.V., Turnbull K.J., The Chapman-Richards generation of Von Bertalanffy's growth model for basal area growth and yield in even-aged stands, For. Sci. 19 (1973) 2-22.

[17] Richards F.J., A flexible growth function for empirical use, J. Exp. Bot. 29 (1959) 290-300.

[18] Schneider W.G., Knowe S.A., Harrington T.B., Predicting survival of planted Douglas-fir and ponderosa pine seedlings on dry, lowelevation sites in southwestern Oregon, New For. 15 (1998) 139159.

[19] Van den Driessche R., Nursery growth of conifer seedlings using fertilizers of different solubilities and application time, and their forest growth, Can. J. For. Res. 18 (1988) 172-180.

[20] Walker R.F., Huntt C.D., Controlled release fertilizer effects on growth and foliar nutrient concentration of container grown Jeffrey pine and singleleaf pinyon, West. J. Appl. For. 7 (1992) 113-117.

[21] Walker R.F., Lane L.M., Containerized Jeffrey pine growth and nutrient uptake in response to mycorrhizal inoculation and controlled release fertilization, West. J. Appl. For. 12 (1997) 33-40.

[22] Wenny D.L., Dumroese R.K., A growing regime for containerized ponderosa pine seedlings, University of Idaho, Forest, Wildlife and Range Experiment Station Bulletin \# 43, Moscow, ID, 1987. 